\title{
A Synchronization Concept of Vocational Education in Indonesia
}

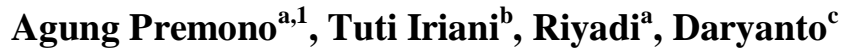 \\ ${ }^{a}$ Departement of Mechanical Engineering, Engineering Faculty, State University of Jakarta, Jakarta, INDONESIA \\ ${ }^{\mathrm{b}}$ Departement of Civil Engineering, Engineering Faculty, State University of Jakarta, Jakarta, INDONESIA \\ ${ }^{c}$ Departement of Electrical Engineering, State University of Jakarta, Jakarta, INDONESIA \\ ${ }^{1}$ premono.agung@gmail.com
}

\begin{abstract}
Vocational education in Indonesia has been implemented in three different levels of education: higher education, secondary education, and non-formal education. However, vocational education implementation of these levels seems not related to each other. This study is carried out to create a synchronization concept of vocational education in all level educations refer to the Indonesian 1 Qualifications Framework (KKNI). Qualitative methods using theoretical and document studies are conducted to formulate the expected results. Results show that the KKNI has provide a framework concept to develop and synchronize vocational education at all level of education. However, implementation of this framework to the curriculum in each level of education has not been made. Therefore, a new concept of vocational education curriculum development is created in this paper.
\end{abstract}

Index Terms - vocational education, the Indonesian Qualifications Framework, curriculum.

\section{Introduction}

In 2015, Indonesia will be a part on Association of South East Asia Nation (ASEAN) community. This means that all of Indonesian people must be prepared to compete with people from ASEAN countries. The main capital to prepare on ASEAN community is the educated people. Therefore, education is the most important factor for all Indonesian people to be a part of ASEAN community era. Basically, Indonesia has been prepared to develop the nation using education. It can be seen in the Indonesian Constitution 1945 article 31. This article consists of five verses which in verse number one declared that every citizen has a right to get the education [1]. However, this article seems not implemented seriously even though the derivative of the constitution has been made.

The other situations to increase education quality in Indonesia are divided into two challenges. There are internal and external challenges. Internal challenge is related to the national education standards which cover contents, processes, graduate competences, teachers and educational employers, facilities, management, finance, and evaluation [2]. Another factor from the internal challenges is related to the Indonesian population growth. At present, total Indonesia people in productive ages are bigger than non-productive ages. Therefore, the biggest problem is how to seek the Indonesia people have competencies and skills using education. The second challenge comes from external. It is related to globalization, environmental problems, information technology, and educational development. In order to face these challenges, vocational education and training is the best way to increase competencies and skills of Indonesian people. Vocational education in Indonesia has been implemented in three different levels of education: higher education, secondary education, and non-formal education. However, vocational education implementation of these levels seems not related to each other. Therefore, quality of graduates of vocational education and training could not guarantee at the same level. With this situation, this study is carried out to create a synchronization concept of vocational education in all level educations refer to the Indonesian National Qualifications Framework (KKNI).

\section{Theoretical Review}

\section{Vocational Education and Training}

Vocational education and training (VET) is education and training which aims to equip people with knowledge, skills, and competences required in particular occupations or more broadly on the labor market [3]. With this definition, vocational and technical education is by design intended to develop skills that can be used in a specific occupation or job [4]. In the same book, Middleton stated that public vocational education and program are inflexible and inefficient compared with skills training offered by employers and private training institutions, which are subject to market forces. This phenomenon occurs in several developing countries including Indonesia. Therefore, training in the private sector-by private employers and in private training institutions-can be the most effective and efficient way to develop the skills of the work force [5].

Basically, Indonesia has been prepared the vocational education and training. It can be seen in the law number 20 years 2003 about Indonesia national education system or in short UU No. 20 years 2003. In this law, several education terminologies are defined. In chapter IV UU No. 20 years 2003 stated that education pathways in Indonesia divided into formal education, informal education, and informal education [6]. Formal education in Indonesia is divided into three levels. There are primary education, secondary education, and higher education. Primary education is a level of education which is underlying of secondary education. It is cover the elementary school level and the junior high school level. Secondary education is a level of education which is underlying of higher education. It covers the senior high school in two system, general senior high school and vocational school. Higher education is a level of education after secondary education. It covers diploma program, bachelor, master, and doctoral degree, which is held in 
several systems such as academy, polytechnic, institute, and university. Meanwhile, types of education in Indonesia encompass into general education, vocational education, academic education, religious education, and special education. Vocational education and training system in Indonesia illustrates on Figure 1.

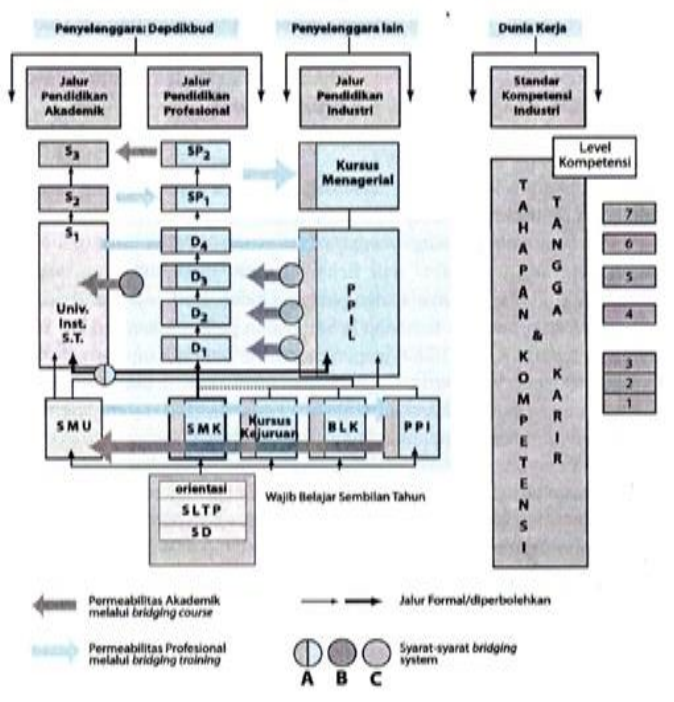

Fig. 1. Vocational training in Indonesia [7]

In order to develop the labor skill from several levels of education, Indonesian government has established some directorates under Ministry of Education and Culture. There are vocational school development directorate (PSMK, stands in Indonesian) for the secondary education, and courses and training directorate (PPTK PAUDNI, stands in Indonesian) for the non-formal education. However, there is no special directorate in the higher education which concentrates on labor skill development (vocational education and training for the higher education). With this structure, VET in higher education seems not to be taken seriously. However, PSMK and PPTK still develop the programs in order to increase skill worker capabilities.

PSMK develops the new paradigms on curriculum development which related to the 2013 curriculum. These paradigms are: (1) balancing between spiritual and social competencies; (2) school as a part of the community where student can implement the material which obtained on the school to the community otherwise community give the material to students; (3) develop attitudes, knowledge, and skills, in further implement it to several situations on schools and community; (4) give an appropriate time to develop attitudes, knowledge, and skills; and (5) basic competencies has been developed on accumulative principles.

For the non-formal education, PPTK PAUDNI has been tried to develop a competencies standards based on industrial and workforce needs. The standards have made on various training skills. However, the main problem on this sector is that the course and training depend on the student requirements and time flexibility.

Vocational and education training problem in higher education is more complex than secondary and non-formal educations. There is no special directorate which is concentrate on VET tasks. Directorate General Higher Education (DGHE), Ministry of Education and Culture, the
Republic of Indonesia has various directorates. However, there is no separation between academic and vocational track. Furthermore, DGHE has been only gave the curriculum framework in each types and levels such as 1st, 2nd, and 3rd grade on polytechnic, or how many credits must be passed for bachelor degree. This framework consists of the compulsory subjects that must be passed. In order to complete the graduation requirement, every institution can develop the curriculum which is suitable with their resources. This development model could be implemented on higher education which is concentrate on academic development, especially university. However, this model is quite difficult to implement on higher education which is concentrate on vocational such as academy or polytechnic because this type concentrates on skill development. Therefore, it must be guided on job competencies based on industrial requirements.

With these three different curriculum development models, it is recommended to develop the competency standard in order to produce the same graduation quality including academic, skills, and attitude at the same level and training. Basically, this standard has been formulated on the Indonesian Qualifications Framework (KKNI) which is discussed in the forthcoming section.

\section{The Indonesian Qualifications Framework (KKNI)}

The Indonesian qualification framework (KKNI stands in Indonesian) is a qualification level and Indonesian labor competencies framework which are equalize, synchronize, and integrate between educational sector, training, and work experience in the workability recognition scheme. This scheme is adjusted to structure on various employment sectors.

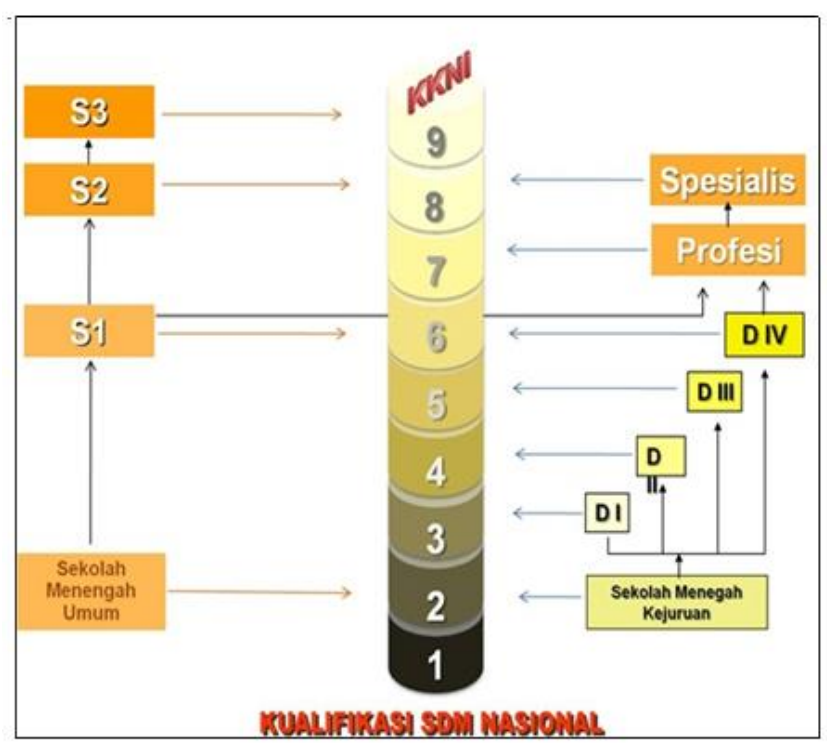

Fig. 2 KKNI's level based on education level [8]

Although the KKNI is adjusted to structure on various employment sectors, the KKNI is standardized based on education graduation leveling. It starts from level 1 which is equivalent to junior high school graduations or less than it. Level 2 in KKNI is equivalent to senior high school graduations including general senior high school or vocational school. Level 3 on KKNI is equivalent to diploma 1 graduation. For the next level, increasing one level on 
KKNI is equivalent to increasing level of education such as level 4 on KKNI is equivalent for diploma 2 graduation and level 5 on KKNI is equivalent for diploma 3 graduation. Bachelor degree graduation is equivalent to level 6 on KKNI, as well as for professional degree graduation is equivalent to level 7 on KKNI, master degree graduation for level 8 on $\mathrm{KKNI}$, and the last level (level 9) on KKNI is equivalent to doctoral degree graduation. This leveling is illustrated on Figure 2.

\section{Discussion}

From theoretical review and present condition, the following steps are proposed to synchronize vocational education at the various levels such as secondary education, higher education, and non-formal education. These are:

1. Competence standards on KKNI should be translated into the curriculum on various level of education. With this translation, the curriculum might be in-line with industrial requirements. The translation must include the contents, learning strategy, facilities requirement, time requirement in order to study a competence standard completely, and an evaluation system which can measure the student competencies. At present, competence standard in KKNI is only a framework which could not be implemented technically on teaching and learning by schools and other types of education. Therefore, interpretation of KKNI in each level and types of education has been done by their own knowledge. In order to realize this concept, the Directorate General of Vocational Education is recommended to be established under Ministry of Labor. This because VET is always associated to Labor and Industrial requirements. This directorate general covers all of VET on several level of education from the higher education till the non-formal education. With this management, continuity from one level to the next level on KKNI can be guarantee. Effect of this strategy is that Ministry of Education and Culture concentrate only on character mold of the next generation (children). The difficulty of VET at all level of education is the gap between theoretical aspects which is given in schools and practical aspects on industrial field. To reduce this gap, cooperation between school and industry must be optimized. It can be easily implemented when the VET and industry are in the same management, the Ministry of Labor.

2. From the human resources, especially teachers and instructors at the various level of education such as polytechnic, SMK, and training center, that they must be understood about KKNI completely. Teachers or instructors on VET institution should have competence certificate which indicates they competencies on a field. Disparities of teachers/instructors ability are severe problems that must be solved. Several methods can be implemented to solve teachers/instructors disparity. These are teacher training program including contents and teaching methods which is related to the subject, or take a degree program that teachers/instructor fulfil the minimum degree requirement. A special training, before teachers/instructors candidates become a professional teacher/instructor, is required to equate teachers/instructors on VET. This training is not only on subject matter but also on teaching-learning methods. This training should be equivalent with the level on
KKNI. This method is a key to increase VET quality because quality of education is nothing without a professional teacher.

3. Beside human resources factor, uniform facilities are the second major priority to create the VET uniformly in Indonesia. VET without facilities is nothing. It because VET is a special education to fulfil workforce requirement. To perform this, student on VET should be creative, innovative, and smart. It can imagine that student on VET have only get a lecture theoretically without practice. However, SMK, Polytechnic, or other VET systems are still weak to fulfil the necessary facilities. Therefore, sharing facilities between one VET institution and the other VET institution can be an alternative solution. An example is the cooperation between State Jakarta Polytechnic (PNJ stands in Indonesian) and Training Centre of Overseas Workers in Bekasi (CEVEST). Human resources, lectures in PNJ and instructors in CEVEST, are become team teaching on a subject matter. Furthermore, most of this cooperation's activities have been done on CEVEST Bekasi. However, student of this cooperation is officially PNJ's student.

4. On teaching and learning process, modularization of subject seems accordance with VET pattern. It because that a module has some characteristics such as integrative function, standard definition, multiple relevance, outcome orientation, and additional competences [9]. Modular frameworks connect the training and education of people in work with training provision for full-time students. This means that modularization is being used to bring school-based and work-based training routes closer together [9]. Moreover, teaching and learning on VET focuses on learn by doing and practice, and learning in groups and have clear guidance [10]. Therefore, it can be implemented on VET in Indonesia.

\section{Conclusion}

Theoretical review and discussion explains that the main problem in VET is how to guarantee that the competence in previous level is basis of the next level on KKNI or how to guarantee that graduation from the upper level on KKNI is always perform the competence at the previous level. To guarantee that all competencies on KKNI is always connecting to each other, some methods are proposed. These are: (1) establish the Directorate General of Vocational Education and Training for all level of education in order to translate KKNI standard into curriculum; (2) increase teachers/instructors knowledge about KKNI; (3) sharing resources between VET institution; and (4) modularization of subject on teaching and learning process.

\section{References}

[1] Indonesia Constitution 1945 (UUD 1945) in Indonesia.

[2] PP Number 19 Years 2005 about National Education Standards, 2005, (in Indonesia).

[3] Nielsen S, "Vocational Education and Training Teacher Training", Elsevier, pp. 503 - 512., 2010.

[4] Midleton J, Ziderman A, and Adams A V, "Skills for Productivity: Vocational Education in Developing Countries", Oxford University Press, 1996.

[5] Midleton J, Ziderman A, and Adams A V, "Vocational and Technical Education and Training", Oxford University Press, 1995

[6] Ministry of National Education, UU No. 20 years 2003 about National Educational System, 2003. (in Indonesia) 
[7] Hasan B, "Pendidikan Kejuruan di Indonesia", downloaded from http://file.upi.edu/Direktori/FPTK/JUR._PEND._TEKNIK_ELEKTR O/195512041981031-

BACHTIAR_HASAN/PENDIDIKAN_KEJURUAN_DI_INDONESI A.pdf., 2014. (in Indonesia)

[8] Directorate General of Higher Education, "Pengembangan Kurikulum LPTK", presentation file on Power Point format, 2012 (in Indonesia).

[9] Ertl H and Hayward G, "Modularization in Vocational Education and Training", Vocational Education and Training - Teaching and Learning, Elsevier, pp. 383 - 390, 2010.

[10] Karmel T, "Vocational Education and Training", Elsevier, pp. 229 239., 2010 